\title{
International Experience of Environmental Taxes and Its Implications for China
}

\author{
Shen Jian-fei \\ School of Continuing Education \\ North China Electric Power University \\ Beijing,China \\ shenjianfei@263.net.cn \\ Sun Qiao \\ School of Economics and Management \\ North China Electric Power University \\ Beijing,China \\ Sq199120062006@126.com
}

\author{
Yi Jing \\ School of Economics and Management \\ North China Electric Power University \\ Beijing,China
}

\begin{abstract}
In today's society, the development of green economy has become an important trend. There is a large population base in our country, and the resources is relative short, as well as the environmental carrying capacity is not strong. In recent years, faced with increasingly severe sandstorms, PM2.5 pollution and other environmental issues, the development of a green economy and the improvement of environmental tax system cannot be delayed anymore. This paper analyzes the experience of environmental tax reform in Europe, America, Japan and other countries with a view to having a reference to China's development and improvement of environmental tax.
\end{abstract}

Keywords-environmental taxes; tax reform; tax mix; tax collection ; international experiences ; implications

\section{INTRODUCTION}

Environmental tax, also known as green taxes or eco-taxes, is rose in international tax circles in the late 20th century. Environmental tax is for the purpose of protecting the environment and resources, with political rights according to the degree of development and utilization of environmental resources or pollution and damage to impose a tax for any unit and individual that developed and utilized environmental resources. China has yet to form a sound environmental tax system, but in the developed countries such as EU, US and Japan, has gradually explore a road for their own development to promote the development of environmental tax and the implementation of the tax reform process.

\section{THE INTERNATIONAL EXPERIENCES OF ENVIRONMENT TAX}

\section{A. Environmental taxation experiences of the European countries}

Environmental taxes in the west began in the $1970 \mathrm{~s}$. Its development has undergone three stages: the compensation cost charge to guide people's behavior way, then to "green tax reform". So far, Denmark, Finland, Germany, Italy, the Netherlands, Norway, Sweden and Britain, totally eight European countries have implemented tax reform. Environmental tax reform framework is shown in the following table I.

TABLE I. ENVIRONMENT TAX REFORM FRAMEWORK

\begin{tabular}{|c|c|c|}
\hline $\begin{array}{c}\text { Countries (began } \\
\text { year) }\end{array}$ & Tax cuts & Tax increases \\
\hline \multirow{3}{*}{ Sweden (1990) } & $\begin{array}{l}\text { The individual } \\
\text { income tax }\end{array}$ & $\mathrm{CO} 2$ \\
\hline & $\begin{array}{l}\text { Agriculture energy } \\
\text { tax }\end{array}$ & $\mathrm{SO} 2$ \\
\hline & $\begin{array}{l}\text { Continue to } \\
\text { education }\end{array}$ & other \\
\hline \multirow{3}{*}{ Denmark (1994) } & $\begin{array}{l}\text { The individual } \\
\text { income tax }\end{array}$ & $\mathrm{CO} 2$ \\
\hline & $\begin{array}{l}\text { The individual } \\
\text { income tax }\end{array}$ & $\mathrm{SO} 2$ \\
\hline & $\begin{array}{c}\text { The social security } \\
\text { payment }\end{array}$ & $\begin{array}{l}\text { Other (gas, water, } \\
\text { electricity, waste, } \\
\text { cars) }\end{array}$ \\
\hline \multirow{2}{*}{$\begin{array}{l}\text { The Netherlands } \\
\text { (1996) }\end{array}$} & $\begin{array}{l}\text { The individual } \\
\text { income tax }\end{array}$ & \multirow{2}{*}{$\mathrm{CO} 2$} \\
\hline & $\begin{array}{c}\text { The social security } \\
\text { payment }\end{array}$ & \\
\hline The UK (1996) & $\begin{array}{c}\text { The social security } \\
\text { payment }\end{array}$ & landfill \\
\hline \multirow{2}{*}{ Finland (1997) } & $\begin{array}{l}\text { The individual } \\
\text { income tax }\end{array}$ & $\mathrm{CO} 2$ \\
\hline & $\begin{array}{c}\text { The social security } \\
\text { payment }\end{array}$ & landfill \\
\hline \multirow{3}{*}{ Norway (1999) } & \multirow{3}{*}{$\begin{array}{l}\text { The individual } \\
\text { income tax }\end{array}$} & $\mathrm{CO} 2$ \\
\hline & & $\mathrm{SO} 2$ \\
\hline & & diesel \\
\hline Germany (1999) & $\begin{array}{c}\text { The social security } \\
\text { payment }\end{array}$ & $\begin{array}{c}\text { Crude oil (petroleum) } \\
\text { products }\end{array}$ \\
\hline Italy (1999) & $\begin{array}{c}\text { The social security } \\
\text { payment }\end{array}$ & $\begin{array}{c}\text { Crude oil (petroleum) } \\
\text { products }\end{array}$ \\
\hline
\end{tabular}

Through the reform of the tax system frame structure, we can see that the reform has the following features: 
Firstly, the trend of development of environment tax system reform is to make the tax burden of labor decreases, performance in the reduction of wage labor costs, such as the individual income tax; or cut the social security contributions of employer or employees to pay.

Secondly, tax transfer amount mainly restricted by two factors, one factor is the relationship between the tax transfer and the industrial competitiveness; another factor is that should pay attention to reduce the tax burden of energy-intensive sector as far as possible.

Thirdly, the energy related department revenue growth. Energy tax is getting more and more social recognition, it helps to reduce greenhouse gas emissions and protect the atmospheric environment.

Lastly, the tax reform in terms of capital and labor can increase tax revenues, help to eliminate the subsidy of environment-harmful corporation.

\section{B. Environmental taxation experiences of the United States}

America's environmental protection work is developing in the situation that its economic has been relatively stable while the serious damage has been carried out to the environment, and the idea is called "pollution first and then treatment". It has been nearly 30 years, started relatively early. The environmental conditions have achieved fundamental improvement in the quality after years' efforts. The significant results of this success largely attribute to the following three points.

Firstly, the US has established a sound environmental protection legal system. The US Congress had put forward a motion of tax emissions to sulfur compounds in 1971.In the early 1980s, the US government took the tax measures into the field of the environment. Currently, US totally has 10 kinds of environmental taxes. Tax incentives mainly reflected in its tax expenditure measures, such as accelerated depreciation, investment tax credits, direct tax relief and so on.

Secondly, the US tax collection procedure is really strict and performs executive ability. The tax department unifies the collection of taxes up to the ministry of finance which will divide the tax funds into the trust fund and the general fund budget, The trust fund will assigned to departments firstly and then transferred to the superfund which is charged by the state environmental protection agency, and this item will be included in federal financial management of the foundation's budget. The means of US environmental tax collection is superb and the departments are centralize. The environmental tax revenues increased year by year while the phenomenon of tax evasion decreases.

Lastly, the US put the environmental defense fund into fiscal management and set up the fund system. The origin of superfund mainly involves federal government budget dial and direct to the federal budget in the management. It mainly covers the environmental aspects of its "national priorities" as the role of the object.

\section{Environmental taxation experiences of Japan}

Until the 1990s, Japan's environment tax is mainly for emissions of pollutants and energy products, its mainly embodies in automobile fuel tax. Since the 1990s, the government stepped up its efforts to protect the environment, environmental tax policy is roughly divided into two categories: One is the taxes which main taxation objects are waste, fuel and vehicle; the other is tax measures related to the waste treatment and pollution control equipment. In order to accomplish the goal of economic development and environmental protection on the premise of the endeavor to reduce the expenditure burden, the Japanese decided to launch a new round of reform of environmental taxation system, which is main focused on carbon tax.

Specified in the reform program, the timing of progress to a certain stage, the rate of energy products can be differential pricing depending on their different category. On this basis, according to the three stages raise tax rates, so you can ensure a better implementation of the tax burden distribution patterns with "low tax rate, broad tax base", to prevent tax burden of some industry or sector is too heavy, and help to ensure that taxation is fair. Meanwhile, raised the tax plan according to the stage, and give tax incentives for specific sectors, can avoid tax surge. Adjustment plan is shown in Table II.

TABLE II. THREE-STAGE TAX ADJUSTMENT PROGRAMS OF THE GLOBAL WARMING SPECIAL TAX

\begin{tabular}{|c|c|c|c|}
\hline $\begin{array}{c}\text { Adjustment } \\
\text { phase }\end{array}$ & $\begin{array}{c}\text { Crude petroleum } \\
\text { products (per kl) }\end{array}$ & $\begin{array}{c}\text { Gas-like } \\
\text { carbohydrates } \\
\text { (per t) }\end{array}$ & $\begin{array}{c}\text { Coal } \\
\text { (per t) }\end{array}$ \\
\hline Existing tax & 2040 & 1080 & 700 \\
\hline $\begin{array}{c}\text { The first phase } \\
01 / 10 / 2011\end{array}$ & 2290 & 1340 & 920 \\
\hline $\begin{array}{c}\text { The second } \\
\text { phase01/04/2013 }\end{array}$ & 2540 & 1600 & 1140 \\
\hline $\begin{array}{c}\text { The third phase } \\
01 / 04 / 2015\end{array}$ & 2800 & 1860 & 1370 \\
\hline
\end{tabular}

The specific application in the scope of exemptions and other incentives which is established by the tax refund system covers those aspects: imports of certain coal, imported or used in domestic petrochemical raw materials, domestic oil and asphalt and so on.

Japanese environmental tax policy has achieved good results in protecting the environment meanwhile radiate to other levels of society. From the impact point of view, for the production sector it will influence the price that the enterprises put into capital goods which will affect the value of their products; for the household sector it directly influences the household disposable income and consumption. Judging from the economic effects, it produces price incentive effects, government financial resources effects and notices effects.

\section{THE PRESENT SITUATION OF ENVIRONMENTAL TAX SYSTEM IN CHINA}

In China, so far the environment tax system has not really set up, it does not have the significance of standardization. In the field of resource tax, based on the price of compensation system is only a single charge system. Our current system think cost is more important than tax, the function of tax is only a supplementary charge system. The environmental policy is also reflected in the consumption tax, income tax, value added tax and 
vehicle and vessel use tax, but it still has not formed the mainstream. Environmental tax and fees policies exposed some questions, it mainly run as follows:

\section{A. The relationship between the tax and cost is a mess. It is difficult to effectively use the method of tax.}

The difference between the tax and fee is obvious in our country. The tax is free, generally does not apply to competitiveness and exclusiveness of public products. And the charging system is not free, so it is suitable for exclusive and monopolistic service and products. In the practice of our country, the existing collection and management difficulties reflected in charging the fees, especially the pollution charge system. If our country apply the tax reform to practice (tax revenue means mandatory and authority), it can straighten out the environmental cost of the current compensation system. Then the environmental protection funds for pollution control and related costs can ensure that all collected. In China, most natural resources are treated as official items, this trait determines that it is more suitable for tax rather than charging system, and many charges matters substantially more tax has a characteristic, therefore, the reform can make the system more reasonable.

\section{B. The tax structure is complicated, and the tax power division between the central and local governments is not clear.}

Our tax system is complex, so it is difficult to operate. Tax is charged by multiple departments, such as finance department and tax department. Thus, tax power division between the central and local government exists unclear circumstances. On the one hand, for a general tax collection resources, the local only has the right to collect, but not the right to control, so the enthusiasm of the collection is not high; on the other hand, in the process of making the laws and regulations of land tax, the local has certain words power, thus it will bring the inconvenience to the union of tax system.

\section{The way to pay the new tax and related facilities are not perfect.}

In the implementation process of the new taxes, facilities are very difficult to achieve effective follow up in a timely manner, the situation of collection system and such facilities not coordinated to a large extent on the new tax operation play a delayed effect, and reduce its implementation efficiency. If the local do an effective management in the light of its own actual, it can effectively ease the contradiction.

\section{It failed to fully achieve the goal of environmental protection.}

First of all, relying on collection of sewage charges cannot solve the problem of environmental protection. China's pollution charge standard is not up to the general standard for environmental governance costs required for the collection of fees, and far apart, unable to regulate pollution emissions. In addition, the current tax system concerning environmental protection aspects of tax is few. Finally, preferential tax policy has improved the economic benefits, at the same time it has also pushed to the ecological environment pollution and destruction.

\section{INTERNATIONAL EXPERIENCE OF ENVIRONMENTAL TAXES AND ITS IMPLICATIONS FOR CHINA}

From analysis of the experience and lessons, for perfecting the environmental tax system in our country, here are some suggestions:

\section{A. Reform current environmental tax system, set up necessary new taxes, unified environment tax is imposed.}

Only rely on the existing environment tax system to meet the protection of ecological environment in our country don't need to be further damage. We can variety multi-level environment tax is imposed, on the basis of the difference between tax rate shall be implemented for industries and products, and degree of pollution coefficient of different pollutants taxed different ratio and the corresponding pollution behavior, make consumers have the right to choose its own energy is beneficial to environmental protection. Levy environment tax, levy object, for the consumer to perform "who consume, who light, wide tax base, light tax burden" principle, put energy tax, resource tax, consumption tax, etc into tax system.

\section{B. Environmental taxation shall work together with other means, strengthening tax collection and administrations build a special fund for environmental tax system}

By using tax means, we need to pay attention to and charge, subsidies, mutual integrated use of economic means such as reward, foster strengths and circumvent weaknesses, mixing and establishing a perfect system of environmental economic policy. Using the difference between tax rates, tax preferential policies, such as actively and effectively will lead to the ecological environmental protection social capital investment. In this part, like super fund system from United States, to establish a special fund way to carry on the management and use the money, realization and protection value of the fund, and further to strengthen the material basis for the environmental protection.

\section{Guarantee the effective implementation of the tax revenue neutral, implement tax rebates.}

Environment filed always has high tax rate, environmentally friendly taxpayers will take a lot of burden. To ease the burden on taxpayers, we can through accelerated depreciation, tax deduction, such as relief preferential tax policies. At the same time, the appropriate measures of tax rebates can better motivate the enthusiasm of the taxpayer.

\section{Make the use of environmental taxes price effect, improve the international competitiveness of domestic medium in long term.}

The introduction of environmental taxes can stimulate the demand for green products, to promote special technology research and development. In the increasingly competitive society, on the question of 
energy conservation and emissions reduction should not only rely on financial support, more to improve the energy structure, the development of new technology. In the process of technological innovation, adjust the industrial structure, improve the international competitiveness.

\section{E. Adopt the management way of localization, call on citizens to set environmental protection tax consciousness, improve environmental legislation.}

Localization of the management style with local specific conditions, on the basis of the actual can ensure the environmental protection work better implementation. Strengthen the propaganda and education, making the environmental protection work with a wide range of solid mass base. For the work of legislation, to be perfect tax economic policy execution according to law, to reduce the phenomenon of tax evasion, to better protect the ecological environment

\section{REFERENCES}

[1] Bai Yanfeng, Carbon Tariff and "Carbon Tax" Policy Adjustment in Existing Tax system [J].Taxation Research, 2011.

[2] Chen Bin, Dilemma and Development of Border Carbon Tax Adjustment. Taxation and Economy, 2011

[3] Sun Gang, The Problems and Suggestions to introduction of environmental tax in China, The institute of Financial Science, 2012

[4] Mumu, The necessity and feasibility of implementation environ-mental tax, Environmental protection and circular economy, 2010
[5] Zhu Le-fang, $\mathrm{Li}$ Wen, The accounting is on the scientific development road by the introduction of environmental tax, Business Economy, 2009

[6] A.M Benton, M.Jacobsen, Environmental Taxes and the Double Divided ypothesis 2010

[7] SHEN Hongman, "Economics of Resources and Environment". Beijing: China Environmental Science Press, 2009.

[8] WANG Keqiang, ZHAO Kai. and LIU Hongmei. "Economics of Resources and Environment”. SHUFE Press, 2007.pp.199-213.

[9] LU Chuanyi. "Economics of Resources and Environment". Tsinghua University Presss, 2012.

[10] CICPA. "Taxation”. Beijing: Economic Science Press, 2010.

[11] REN Hong mei. "Probing into Reform of Sewage Charges System Based on Environmental Protection". Journal Of Weinan Teachers College. Weinan, Vol.25 No.4 pp.46-48, April 2010.

[12] China Development and Reform Commission. "China will pro-mote the treatment of sewage fees and waste disposal fees energy conservation". China Building Material Re-sources Communication. Beijing, pp.4, May.2009.

[13] XIAO Jianhua. "The origion, Current condition and future trend of China's environmental taxes under dual restrictions". Modern Economic Research. Nanjing, pp.35-39, May 2009.

[14] LI Botao. "The International Comparison of the Environmental Taxes and it's Indication to China". Ecological Economy. Kun-ming, Vol.228. pp. 67-69. June.2013.

[15] Sterner T. "Policy Instruments for environmental and natural resource management". Washington DC: RFF Press, World Bank and Sida, 2012.

[16] Swedish Environmental Protection Agency. "Environmental taxes in Sweden-Economic instruments of environmental policy". Stockholm, 2010. 